\title{
BMJ Open What are potential barriers and enablers to patient and physician participation in Canadian cell therapy trials for stroke? A stakeholder interview study
}

\author{
Manoj M Lalu (D) ,, ${ }^{1,2}$ Madison Foster, ${ }^{2}$ Justin Presseau, ${ }^{2,3}$ Dar Dowlatshahi, ${ }^{4,5}$ \\ Gisell Castillo, ${ }^{2}$ Analyssa Cardenas, ${ }^{2}$ Whitney Tam, ${ }^{2}$ Jennifer Zlepnig, ${ }^{6}$ \\ Deborah Timpson, ${ }^{7}$ Yuan Yi Dong, ${ }^{6}$ Pascale Juneau, ${ }^{2}$ Dean A Fergusson ${ }^{2}$
}

To cite: Lalu MM, Foster M, Presseau J, et al. What are potential barriers and enablers to patient and physician participation in Canadian cell therapy trials for stroke? A stakeholder interview study. BMJ Open 2020;10:e034354. doi:10.1136/ bmjopen-2019-034354

- Prepublication history and additional material for this paper are available online. To view these files, please visit the journal online (http://dx.doi. org/10.1136/bmjopen-2019034354).

MML and MF contributed equally.

Received 16 September 2019 Revised 11 February 2020 Accepted 14 February 2020
Check for updates

(C) Author(s) (or their employer(s)) 2020. Re-use permitted under CC BY-NC. No commercial re-use. See rights and permissions. Published by BMJ.

For numbered affiliations see end of article.

Correspondence to Dr Dean A Fergusson; dafergusson@ohri.ca

\section{ABSTRACT}

Objectives Early phase cell therapy trials face many barriers to successful, timely completion. To optimise the conduct of a planned clinical trial of mesenchymal stem cell (MSC) therapy for chronic stroke, we sought patient and physician views on possible barriers and enablers that may influence their participation.

Design Semistructured interview study.

Setting Patients were recruited from three rehabilitation centres in Ontario, Canada; physicians were recruited from across Canada through snowball sampling.

Participants Thirteen chronic stroke patients (patients who had experienced a stroke at least 3 months prior; 10 male, 3 female) and 15 physicians (stroke physiatrists; 9 male, 6 female) participated in our interview study. Data adequacy was reached after 13 patient interviews and 13 physician interviews.

Methods Interview guides and directed content analysis were based on the Theoretical Domains Framework (TDF). Interviews were coded, and relevant themes were identified. Results Most patients were optimistic about participating in an MSC therapy clinical trial, and many expressed interest in participating, even if it was a randomised controlled trial with the possibility of being allocated to a placebo group. However, the method of administration of cells (intravascular preferred to intracerebral) and goal of the trial (efficacy preferred to safety) may influence their intention to participate. All physicians expressed interest in screening for the trial, though many stated they were less motivated to contribute to a safety trial. Physicians also identified several time-related barriers and the need for resources to ensure feasibility.

Conclusions This novel application of the TDF helped identify key potential barriers and enablers prior to conducting a clinical trial of MSC therapy for stroke. This will be used to refine the design and conduct of our trial. A similar approach may be adopted by other investigators considering early phase cell therapy trials.

\section{INTRODUCTION}

Patient recoveries following stroke tend to plateau in the chronic phase resulting in continued deficits. ${ }^{1}$ A number of preclinical studies suggest mesenchymal stem cells (MSCs)
Strengths and limitations of this study

- Our study addresses an important gap in the literature: assessing barriers and enablers to participation in early phase trials.

Our interview guides and analyses were informed by the Theoretical Domains Framework.

- The individuals who participated in our interview study may generally be more open to participating in research and thus have different views from those who declined to participate.

- This interview study provides a needed comprehensive analysis of a novel topic.

may be effective in the treatment of ischaemic stroke $^{2}$ given their anti-inflammatory properties, ${ }^{34}$ ability to generate trophic factors ${ }^{2}$ and potential regenerative capacity. ${ }^{5}$ Recent systematic reviews of MSC therapy for stroke suggest that the treatment appears safe; however, larger, more rigorously designed trials are needed to assess its safety and efficacy. ${ }^{6}$

When planning clinical trials, ensuring feasibility is of great importance; many trials do not meet intended recruitment objectives by anticipated deadlines $(86 \%)$ or at all $(19 \%) .^{78}$ This suggests that engagement of patients and physicians in clinical trials needs to be improved. Systematic reviews have identified multiple barriers to trials including treatment preferences, issues with consent and information, fear of potentially endangering physician-patient relationships and a shortage of resources. ${ }^{9} 10$ However, available studies on these issues are retrospective, have methodological limitations and focus on later phase trials. Within the field of early phase cell therapy trials, there is a paucity of data on the barriers and enablers to patient and physician participation in clinical trials. A recent narrative review discussing a group's 
experience in recruitment for cell therapy for stroke trials identified several potential patient barriers, including misconceptions regarding stem cells and a preference for single arm designs ${ }^{11}$; however, a formal assessment of barriers was not performed.

In preparation for a new clinical study of MSC therapy for chronic stroke, we sought to prospectively identify potential barriers and enablers using the Theoretical Domains Framework (TDF). The TDF is an established framework that synthesises theories of behaviour change into a parsimonious set of domains that represent influences on decisions and actions: knowledge, skills, social/ professional role and identity, beliefs about capabilities, optimism, beliefs about consequences, reinforcement, intentions, goals, memory, attention and decision processes, environmental context and resources, social influences, emotion and behavioural regulation. ${ }^{12}$ The TDF is commonly applied to identify barriers and enablers to healthcare provider behaviour change using interviews or surveys. ${ }^{13}$ The TDF has been used to prospectively identify potential barriers and enablers to clinical trial participation, such as physician involvement and parent participation in a stem cell therapy trial for neonatal bronchopulmonary dysplasia to inform an early-phase clinical trial ${ }^{14}$ and healthcare provider ordering and setting of individualised dialysis temperature to inform a large-scale pragmatic cluster randomised trial. ${ }^{15}$ Here, using a comprehensive, qualitative interview approach, we applied the TDF to investigate barriers and enablers that would influence patient and physician participation in a clinical trial of MSC therapy for chronic stroke.

\section{METHODS \\ Ethics}

Written and/or verbal informed consent was obtained from all participants, and all procedures followed were in accordance with institutional guidelines.

\section{Patient and public involvement}

Patient input was obtained on the development of the interview guide. Two patients provided feedback on the interview guide. Refinements based on this feedback were made by the research assistant.

\section{Interview topic guide}

The TDF (version 2) ${ }^{12} 16$ was used to develop semistructured interview guides for both populations. The TDF synthesises key psychology and behaviour change theories and associated constructs into 14 theoretical domains that can be applied to understand barriers and enablers to behaviour change. ${ }^{12}{ }^{16}$ For this study, behaviours of interest were defined using the Action, Actor, Context, Target, Time (AACTT) framework to ensure study of specific behaviours (table 1) ${ }^{17-19}$ Details of the interview guide can be found in online supplementary methods I-III.

\section{Participants}

Patients

Stroke survivors who had suffered a stroke at least 3 months prior were identified by physiatrists at their discharge from stroke rehabilitation at one of three centres: a rehabilitation centre within a tertiary care centre, an inpatient rehabilitation centre and an inpatient and outpatient rehabilitation centre within a regional care centre. Patients were provided with an information sheet explaining the study rationale. This description stated that laboratory studies suggest MSCs may be beneficial for stroke survivors and that we were interested in understanding patients' current beliefs and knowledge to help improve a planned trial. Patients who were interested and who consented to having their contact information passed on to the research team were contacted by the lead research assistant. The research assistant answered patients' questions and, if they were still interested, set up a time for the interview. Written and/or verbal informed consent was obtained.

\section{Physicians}

Snowball sampling was used to identify stroke physiatrists from across Canada; potential participants were approached with an information sheet by email. To ensure diversity of viewpoints, we asked the participants to refer physicians who may have differing opinions.

\section{Procedure}

Research assistants with backgrounds in health science were trained in conducting interviews, and using the TDF to inform data collection and analysis. Research assistants

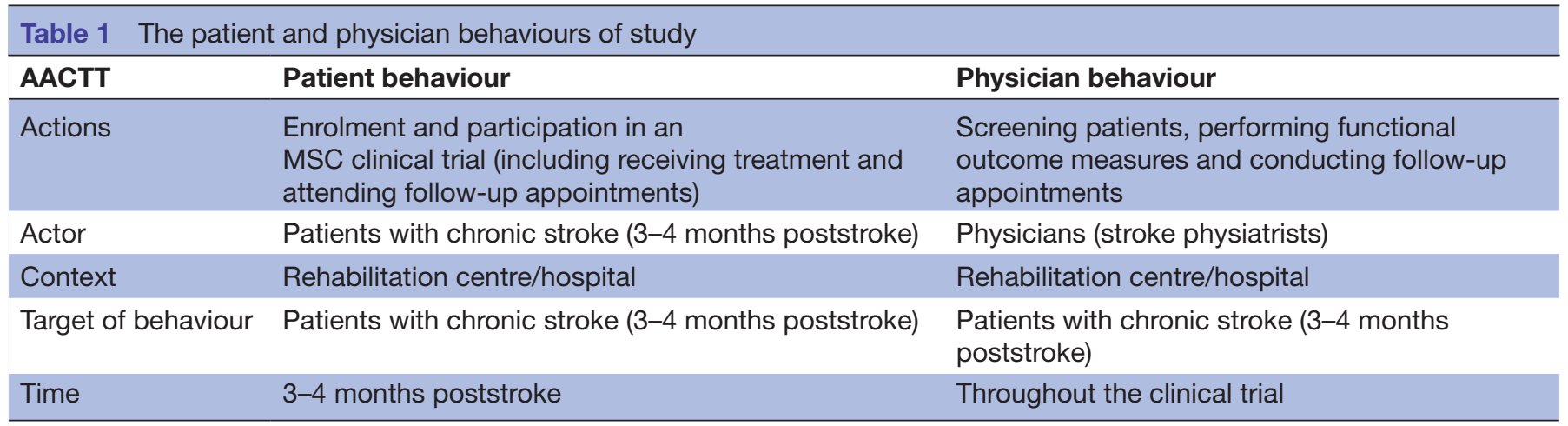

MSC, mesenchymal stem cell. 
conducted all interviews by phone or in person at the rehabilitation centre (PJ, WT, AC and JZ). Participants could be accompanied by a caregiver (family or friend) during the interview if they preferred. Sample sizes were determined using a $10+3$ stopping rule. ${ }^{20}$ After 13 interviews were conducted, data were considered adequate if no new themes emerged within the last three consecutive interviews.

Semistructured interview guides were used, and participants were encouraged to expand on their answers. At the beginning of the interview, the research assistant explained to patients and physicians current evidence regarding MSCs in treating subacute and chronic stroke. They also described the potential mechanisms of action and noted that we are only just beginning to learn about the different benefits and risks; however, existing clinical evidence suggests this therapy may be safe. The research assistant then explained that our team plans to conduct an early phase trial, in which the main goal is to confirm that MSCs are safe. All interviews were recorded, transcribed and pseudonymised.

\section{Data analysis}

Using NVivo 10 (QSR International, Australia) a directed content analysis was conducted. ${ }^{21}$ Consistent with guidance published by Atkins $e t a l{ }^{13}$ analysis was led by a primary analyst who coded each interview transcript by selecting relevant excerpts and assigning them to one of the theoretical domains from TDF version 2 (WT and $\mathrm{AC}) .{ }^{16}$ A secondary analyst, blinded to the primary researcher's assignments, subsequently coded the selections to TDF domains (JZ and YYD). Conflicts were resolved through discussion or a senior investigator (JP and ML). Two pilot interviews were coded and used to develop a common coding strategy to ensure consistency. The final coding strategy was developed with oversight by a researcher experienced in application of the methods used (JP).

\section{Generation of belief statements and identification of relevant domains}

All excerpts coded into a TDF domain (ie, from across all interviews) were examined to identify key underlying beliefs and generate belief statements. ${ }^{22}$ Relevant domains were identified based on: (1) the frequency with which a belief was mentioned by different participants, (2) the presence of opposing beliefs and (3) evidence of strong beliefs in a domain that may impact decisions to participate in a clinical trial of MSC therapy for chronic stroke. ${ }^{22} 23$ Overarching themes spanning the relevant domains were then generated.

\section{RESULTS}

\section{Patient sample characteristics}

Twenty-four patients were approached and 13 agreed to participate in semistructured interviews; all interviews were completed over the phone (table 2). Participants (10

\begin{tabular}{lc}
\hline \multicolumn{2}{l}{ Table 2 Sample characteristics for patients $(\mathrm{n}=13)$} \\
\hline Characteristic & $\mathbf{n}(\%)$ \\
\hline $\begin{array}{l}\text { Sex } \\
\quad \text { Male }\end{array}$ & $10(77)$ \\
$\quad$ Female & $3(23)$ \\
Time passed since stroke, months & \\
$0-4$ & $7(54)$ \\
$>4-8$ & $3(23)$ \\
$>8-12$ & $1(8)$ \\
$12+$ & $2(15)$ \\
Age, years & \\
$18-35$ & $2(15)$ \\
$>35-50$ & $1(8)$ \\
$>50-65$ & $3(23)$ \\
$>65-80$ & $7(54)$ \\
\hline
\end{tabular}

male, 3 female) had a median age of 67 (range 25-79). Two patients had experienced more than one stroke. Interviews ranged in duration from $17 \mathrm{~min}$ to $37 \mathrm{~min}$, with a median interview time of $25 \mathrm{~min}$. Data adequacy was reached after the 13 th interview. ${ }^{20}$

\section{Physician participant characteristics}

A total of 40 Canadian stroke physicians were approached and 15 participated in semistructured interviews (spanning Canadian provinces of British Colombia, Alberta, Manitoba, Ontario and Nova Scotia). Fourteen interviews were conducted over the phone, while one was conducted in-person. Of these, 13 interviews were fully coded and included here as data adequacy was reached as per our predefined sample size rule. ${ }^{20}$ Physicians (seven male, six female) had been practising for 3-35 years, and a median of $25 \%$ of patients in their practices had chronic stroke (range $=5 \%-60 \%)$ (table 3). Median interview time for physicians was 25 min (range 15-31 min).

\section{Relevant domains}

Eleven domains were deemed relevant to patients and 13 domains were deemed relevant to physicians. Tables $4-5$ and online supplementary table I-II expand on key belief statements and sample quotes.

\section{Key themes identified from patient interviews}

Patient key theme 1: patients are optimistic and perceive potential benefits to participating in an MSC therapy trial (optimism, beliefs about consequences, social/professional role and identity, intention, beliefs about capabilities and goals)

Almost all patients were optimistic that participating in an MSC therapy trial for chronic stroke would result in more good things than bad. Some patients expressed that an efficacy trial may directly benefit them as well as others in the future. All interviewed patients identified that health benefits (eg, 'to get better', reverse the damage, symptom reduction and prevention of future strokes) and/or 


\begin{tabular}{lc}
\hline \multicolumn{2}{l}{ Table 3 Sample characteristics for physicians $(\mathrm{n}=13)$} \\
\hline Characteristic & $\mathbf{n}(\%)$ \\
\hline Sex & $7(54)$ \\
$\quad$ Male & $6(46)$ \\
$\quad$ Female & \\
Experience as a physiatrist, years & $5(38)$ \\
$0-10$ & $7(54)$ \\
$>10-25$ & $1(8)$ \\
$25+$ & \\
Experience screening for a clinical trial & $9(69)$ \\
Yes & $4(31)$ \\
No & \\
Percentage of stroke patients seen & $7(54)$ \\
$0-25$ & $5(38)$ \\
$>25-50$ & $1(8)$ \\
$>50-100$ &
\end{tabular}

functional improvement would be an important goal of participating in the trial.

Most patients said they would consider enrolling in the trial if one were to be available in the next year and most also said that they would feel confident in their ability to enrol and/or participate. Interestingly, almost all patients expressed that the prospect of a placebo group would not affect their decision to participate in a negative way. Some patients reasoned that this would still allow them the chance to receive therapy, as compared with not participating at all.

Well to me, I'm already in the non-treatment group. So, the only thing that would be different is that I could be in the treatment group. - Patient 5

Patient key theme 2: patients have some concerns about risks, uncertainty and safety (beliefs about consequences, intention and emotion)

Although several patients stated that they did not think the trial would have any negative aspects, most patients did express concern regarding the potential side effects of MSCs. Some patients also voiced that they were unsure of what the consequences or benefits would be. However, there were opposing views as to whether a safety (vs efficacy) trial would affect their intention to participate. Almost half of those interviewed said their motivation would not be affected if the purpose of the study was to assess safety rather than efficacy. In contrast, some patients expressed that they would be less motivated to participate in a safety trial.

I would be not very motivated if it was just to check the safety of it. Because it's saying, wow... that you're really a guinea pig.... - Patient 10
Several patients also expressed that the method of administration would affect their decision to participate in the trial (ie, intravascular preferred over intracerebrally).

Patient key theme 3: patients want more information and resources

Almost all interviewed patients expressed limited knowledge of MSCs and suggested they would require more information on risks and benefits of MSCs and available alternative therapies. The majority of patients did not have any moral or ethical issues with the idea of 'stem cells'. Several patients noted that logistical factors, such as location and time considerations, would weigh into their decision to participate. A majority also identified transportation or financial reimbursement as key resources to enable participation. Only one patient felt that they would not require any additional resources to participate.

Patient key theme 4: physicians, researchers and family would influence intention to participate (social influences)

Almost all patients identified that opinions of researchers and their physicians or family would impact their decision to participate. When asked how they would go about enrolling in a clinical trial, almost half of the patients interviewed stated that they would enrol through their physician; however, several mentioned they would respond to other sources (eg, newspaper and online advertisements).

\section{Key themes identified from physician interviews}

Physician key theme 1: physicians feel capable and motivated Almost all physicians interviewed were generally optimistic that a trial to assess MSC therapy for chronic stroke would provide several benefits for both patients and themselves. All physicians said they would consider participating in the trial if available in the next year and most physicians said they would feel confident in their ability to screen or refer patients for the trial.

Physician key theme 2: concerns about risks, uncertainty, safety and the need for more information about MSCs (beliefs about consequences, intention and knowledge)

Specific knowledge on MSCs varied across physicians; one explicitly expressed that they 'don't know anything about [MSCs]' (Physician 7), while most reported awareness or some knowledge of cell therapy. Most physicians expressed that there may be disadvantages to patients or that they were unsure of the consequences of treating patients with MSCs. Similarly, most physicians reported that the safety of MSCs would play a large role in their decision to screen for the trial.

I would like to know that ... the safety issue has been sorted out so that I can say to my patients, 'It has been shown that they are safe'. - Physician 3

Similar to patients, there were conflicting views as to whether the primary goal of the trial (safety vs efficacy) would affect their motivation to become involved; most expressed that they would still be motivated to screen for 
Table 4 Summary of belief statements and sample quotes from patients assigned to domains identified as relevant

\begin{tabular}{|c|c|c|c|}
\hline Domain & Specific belief & $\begin{array}{l}\text { Frequency (out } \\
\text { of } 13)(n(\%))\end{array}$ & Sample quote \\
\hline \multirow[t]{4}{*}{ Goals } & $\begin{array}{l}\text { I would like to see my own health/ } \\
\text { function improve. }\end{array}$ & $13(100)$ & $\begin{array}{l}\text { 'Well I'm still not walking yet. I would like to be more mobile...' (P3). } \\
\text { 'Well for me because I want to recover like not quicker but I want recover... I just started my life, I } \\
\text { want to go back to work and do all these things' (P13). }\end{array}$ \\
\hline & $\begin{array}{l}\text { This trial would be one of my top } \\
\text { priorities. }\end{array}$ & $8(62)$ & $\begin{array}{l}\text { (If you were participating in a clinical trial, how often might something else be more urgent than } \\
\text { attending a follow-up appointment?) 'I organize my life pretty well so I don't think you would- if I had } \\
\text { an appointment I would be there' ( } \mathrm{P} 10) \text {. }\end{array}$ \\
\hline & $\begin{array}{l}\text { This trial would be one of my top } \\
\text { priorities, but other urgent matters } \\
\text { could affect my participation. }\end{array}$ & $5(38)$ & $\begin{array}{l}\text { 'Again, something like a death. Other than that, this should be a major concern to the individual to } \\
\text { honour your commitment' (P4). } \\
\text { '... Well the only other thing is that I've got doctors to see but I suppose that's the only thing' (P9). }\end{array}$ \\
\hline & $\begin{array}{l}\text { Trial appointments would be important } \\
\text { to me, but something else would be } \\
\text { more of a priority. }\end{array}$ & $1(8)$ & $\begin{array}{l}\text { (If you were participating in a clinical trial, how often might something else be more urgent than } \\
\text { attending a follow-up appointment?) 'My appointments would all be important to me'. (Would there be } \\
\text { anything else that is more urgent than the appointment?) 'Yeah it would depend on what's going on } \\
\text { with my son at school. My son comes first in my life' (P2). }\end{array}$ \\
\hline \multirow[t]{2}{*}{ Knowledge } & I have no/limited knowledge of MSCs. & $12(92)$ & $\begin{array}{l}\text { (Have you heard of MSCs before?) 'No I haven't' (P2). } \\
\text { 'Not that much I guess...' (P11). }\end{array}$ \\
\hline & I am aware of/ have some knowledge & $1(8)$ & 'I know about stem cells, I read about them. What stem cells do in different cases and so on' (P8). \\
\hline
\end{tabular}
about MSCs.

I would require/like more information.

'... I would have to understand how long is it, what does it involve, what are- what's the advice of my physiatrist...' (P10).

I guess what the risks and potential benefits could be. Any alternative forms of treatment, like potential treatments to- as well to make an informed decision' (P11).

I would not require more information.

'Nope, nope. I'm an old (gender), what do I need to know. Just go for it' (P8).

I have some knowledge regarding $10(77)$

'I know that it's, I guess it's like before a drug or a method or treatment is launched to the public, I clinical trials. guess they're clinical trials that happen to check and make sure they work and get data on how it works' (P11).

I have no/limited knowledge of clinical 4 (31)

(So what do you know about clinical trials?) 'Nothing' (P7); 'Not very much' (P9).

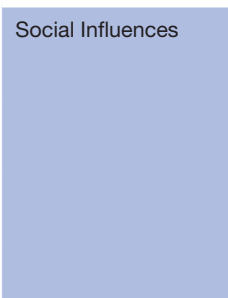

Intention trials.

The opinions of an expert (eg, doctor

or scientist) will have an impact on my decision to participate.

My family's opinions could impact my decision.

I would want to receive information from someone not involved in the trial.

Others' opinions do not have a large influence on my decision.

Being placed in the placebo vs

treatment group would not affect my

decision to participate in a negative

way.

Being placed in the placebo vs

treatment group may affect my

decision to participate.

I would consider participating in the

trial if it were available.

I would not participate in the trial if it were available.

I am unsure if I would participate in a trial if it were available.

I would not be less motivated to participate in the trial if it only assessed safety and not efficacy.

I would be less motivated to participate in a safety trial.

The method of MSC administration would affect my decision to participate.

The method of MSC administration would not affect my decision to participate.

My emotions would affect my decision to participate in the trial in a negative way.

My emotions would not affect my decision to participate in the trial.

I would hope for/expect good things or 12 (92) more good things than bad things.

\section{$12(92)$}

$9(69)$

$1(8)$

$1(8)$

$12(92)$
'I suppose [scientists and researchers from the study would influence my decision]' (P9).

'I would like to get that information from a physiatrist who specialises in stroke recovery' (P10).

(Who do you think would influence your decision the most (to participate in this trial)?] 'My family' (P6).

... a physiatrist which specializes in stroke recovery... not really opinionated on it- I would just have it from a person independent rather than a person who is a tie to this...' (P10).

(Whose opinion is important to you when considering whether to participate in a stem cell trial for chronic stroke?) 'Mostly mine' (P12).

'Well I don't think it would affect me at all. I think I would still want to try something' (P2).

'Well to me, l'm already in the non-treatment group. So, the only thing that would be different is that I could be in the treatment group' (P5).

'... Like if I had to go to a particular- if it was over 2 months and I had to go to a particular place at a particular time everyday then, I would think "oh boy, that might not be worth it" unless I was getting some experimental treatment that I was confident in. So it would affect it somewhat ...' (P10).

'....if there was any chance of stem cell research helping correct what problems I have because of the stroke then of course count me in for it...' (P8).

'No, I wouldn't participate no' (P7).

'Oh I don't know that I would' (P10)

(You'd be okay with testing the safety of the stem cells?) 'Yes, absolutely. You have to start somewhere' (P8).

'I would be not very motivated if it was just to check the safety of it. Because it's saying, wow the- that you're really a guinea pig on your mortality' (P10).

(Would it influence your motivation if the cells were injected into your brain or applied through an IV?) 'I think it would, like IV- I would yeah... injecting into your brain, I would be scared...' (P13).

'I don't think it would change me at all. It would probably work or it doesn't and if the only way it's going to work is through the brain then so be it...' (P4).

(How would these emotions then influence whether you wish to participate in the stem cell trial? Would it make you want to participate more or less?)

'Less, yeah, more worried and nervous and stuff like that. Yeah less' (P13).

How would the emotions you mentioned to me influence whether you wish to participate in the stem cell trial? Would it ... make you want to participate more or less?) 'Participate the same, it's still- I could do it, it wouldn't be any less at all' (P12).

'Well because I don't think that researchers or scientists would be embarking on something that the probability is bad rather than good, so I would have confidence that there's a bigger possibility of it doing good than harm' (P10).

Continued 
Table 4 Continued

\begin{tabular}{|c|c|c|c|}
\hline Domain & Specific belief & $\begin{array}{l}\text { Frequency (out } \\
\text { of } 13)(n(\%))\end{array}$ & Sample quote \\
\hline
\end{tabular}

Social/ Professional I do not see any moral or ethical issues 10 (77) 'No, I don't have any moral or ethical issues. If it helps humanity, it's a good thing' (P8).

Role and Identity with MSC treatment.

I do see moral and ethical issues with $\quad 1$ (8) (Do you see any moral or ethical issues?) 'Yes, that's a good question. I would have a hard time living receiving MSC treatment. with this decision' (P3).

\begin{tabular}{|c|c|c|c|}
\hline \multirow{9}{*}{$\begin{array}{l}\text { Environmental } \\
\text { Context and } \\
\text { Resources }\end{array}$} & $\begin{array}{l}\text { Transportation/parking is a factor in my } \\
\text { decision to participate. }\end{array}$ & $8(62)$ & 'Yeah I mean, parking and/or transportation would be nice. It would be encouraging I guess' (P11). \\
\hline & $\begin{array}{l}\text { Transportation is not a factor in my } \\
\text { decision to participate. }\end{array}$ & $1(8)$ & $\begin{array}{l}\text { (What resources would you need?... Anything else?) } \\
\text { 'No. I have my own vehicle so' (P2). }\end{array}$ \\
\hline & $\begin{array}{l}\text { Logistical factors (eg, location and } \\
\text { time) would influence my decision. }\end{array}$ & $7(54)$ & $\begin{array}{l}\text { 'Well, I live in [location] so we're talking }(X) \text { hours length of time one way. I'm still not mobile. I'm in a } \\
\text { wheelchair. I'm unable to walk yet' (P3). }\end{array}$ \\
\hline & $\begin{array}{l}\text { I feel like I can rely on the healthcare } \\
\text { system to support me if things get } \\
\text { tough. }\end{array}$ & $6(46)$ & $\begin{array}{l}\text { 'Yes, I can rely on the health care' (P9). } \\
\text { 'Well I would hope so. I have much experience with it' (P3). }\end{array}$ \\
\hline & $\begin{array}{l}\text { I have doubts on whether I can rely } \\
\text { on the healthcare system if things get } \\
\text { tough. }\end{array}$ & $5(38)$ & 'Right now, I don't have a whole lot of faith in the healthcare system' (P4). \\
\hline & $\begin{array}{l}\text { I feel like I can somewhat rely on the } \\
\text { healthcare system to support me if } \\
\text { things get tough. }\end{array}$ & $1(8)$ & 'I could rely on it but also kind of slow' (P13). \\
\hline & $\begin{array}{l}\text { Financial reimbursement, coverage or } \\
\text { an incentive would be helpful. }\end{array}$ & $4(31)$ & 'As long as it's covered by healthcare. [Also depends] If- parking is expensive at the hospital' (P12). \\
\hline & $\begin{array}{l}\text { Making sure my dependent family } \\
\text { members are taken care of is a factor } \\
\text { in my decision to participate. }\end{array}$ & $2(15)$ & $\begin{array}{l}\text { '(Do you need caregivers for your parents?) Oh yeah, yeah so maybe- well- yeah- they'll always be } \\
\text { with me so yeah' (P13). }\end{array}$ \\
\hline & $\begin{array}{l}\text { I have sufficient resources to } \\
\text { participate in an MSC trial. }\end{array}$ & $1(8)$ & 'I don't need any resources' (P8). \\
\hline \multirow[t]{7}{*}{$\begin{array}{l}\text { Beliefs about } \\
\text { Consequences }\end{array}$} & $\begin{array}{l}\text { I am concerned about the potential } \\
\text { risks/harm. }\end{array}$ & $8(62)$ & $\begin{array}{l}\text { '... Maybe it would increase the probability of death or side effects that might- that there are no[ne] } \\
\text { now. As soon as you got a trial there's a little bit of risk, if there wasn't any risk they would just put it } \\
\text { on the market right away' (P10). }\end{array}$ \\
\hline & $\begin{array}{l}\text { I do not perceive any negative } \\
\text { consequences to participating in a trial } \\
\text { of MSCs. }\end{array}$ & $5(38)$ & $\begin{array}{l}\text { 'It can’t get any worse so I don't see any' (P5). } \\
\text { 'I don't see any negative. I am an optimist so I don't really see anything negative' (P8). }\end{array}$ \\
\hline & $\begin{array}{l}\text { This trial has the potential to benefit } \\
\text { me. }\end{array}$ & $5(38)$ & $\begin{array}{l}\text { 'Well the advantage that I would see is that if I have significant residual effect that is chronic stroke } \\
\ldots \text { and stem cell therapy is going to be a worthwhile therapy then to get in at it- at the leading edge } \\
\text { would be some advantage...' (P10). }\end{array}$ \\
\hline & This trial will not benefit me. & $2(15)$ & $\begin{array}{l}\text { (What are some potential negative aspects that you see of participating in this clinical trial?) 'One is } \\
\text { going to the trial and being in the placebo and going through all that, whatever it is and not having any } \\
\text { effect and all. All I would be doing is helping science which is cool, but it isn't something that is going } \\
\text { to be therapeutic for me...' (P10). }\end{array}$ \\
\hline & $\begin{array}{l}\text { This trial will benefit others in the } \\
\text { future. }\end{array}$ & $4(31)$ & $\begin{array}{l}\text { 'And second of all, helping to make hopefully a successful treatment available to others in the future } \\
\text { based on that clinical trial' (P11). } \\
\text { '... if it doesn't work for me and people weren't recommended so then that's a negative for me. But } \\
\text { then it's also a benefit that people will know that this doesn't work and you'll try something else' (P13). }\end{array}$ \\
\hline & $\begin{array}{l}\text { This trial would benefit everyone } \\
\text { involved. }\end{array}$ & $1(8)$ & $\begin{array}{l}\text { 'Well, this is post-stroke right? Not to prevent stroke? (Yes) Well it would help everyone involved I } \\
\text { guess' (P5). }\end{array}$ \\
\hline & $\begin{array}{l}\text { I am not sure if the trial will have } \\
\text { benefits. }\end{array}$ & $2(15)$ & $\begin{array}{l}\text { 'Well, I guess that's the purpose of the trial. I don't know. The researchers, they would find that out' } \\
\text { (P5). }\end{array}$ \\
\hline $\begin{array}{l}\text { Beliefs about } \\
\text { Capabilities }\end{array}$ & $\begin{array}{l}\text { I do feel confident in my ability to enrol/ } \\
\text { participate in a trial of MSCs. }\end{array}$ & $8(62)$ & $\begin{array}{l}\text { (How confident are you that you could participate in a trial of stem cells for chronic stroke?) '100\%' } \\
\text { (P12). } \\
\text { 'Fairly confident' (P5). }\end{array}$ \\
\hline \multirow[t]{3}{*}{ Skills } & $\begin{array}{l}\text { I would use various resources/skills in } \\
\text { order to enrol in a trial of MSCs. }\end{array}$ & $7(54)$ & $\begin{array}{l}\text { 'To my knowledge, generally it'd be a publication in the newspaper or perhaps on the website. I can } \\
\text { apply that way' (P4). }\end{array}$ \\
\hline & $\begin{array}{l}\text { I would contact my physician in order } \\
\text { to enrol in a trial of MSCs. }\end{array}$ & $6(46)$ & $\begin{array}{l}\text { (So what steps would you take to enrol and participate in a stem cell trial?) } \\
\text { 'Again, probably through my doctor' (P12). }\end{array}$ \\
\hline & $\begin{array}{l}\text { I am unsure how to enrol in a trial of } \\
\text { MSCs. }\end{array}$ & $2(15)$ & 'I have no idea' (P7). \\
\hline \multirow[t]{4}{*}{ Emotion } & $\begin{array}{l}\text { I feel happy/hopeful about participating } \\
\text { in an MSC trial and the potential } \\
\text { outcomes. }\end{array}$ & $6(46)$ & 'I would feel happiness. I would be helping out I hope' (P2). \\
\hline & $\begin{array}{l}\text { I feel anxious/fearful about } \\
\text { participating in an MSC trial. }\end{array}$ & $6(46)$ & $\begin{array}{l}\text { 'I'm not sure [laughs], l'd just be afraid to participate' (P7). } \\
\text { 'Emotions... anxiety. (Anything else?) Trepidation, uh fear' (P10). }\end{array}$ \\
\hline & I would feel a mixture of emotions. & $2(15)$ & 'Well I would say everything, so you name it. (Lists examples) Yeah. (All of the above?) Yeah' (P3). \\
\hline & $\begin{array}{l}\text { I do not think I would feel any } \\
\text { emotions, or I am not sure how I would } \\
\text { feel about participating in an MSC trial. }\end{array}$ & $2(15)$ & $\begin{array}{l}\text { 'No emotions' (P7). } \\
\text { 'None of the above. No, it's an unknown. So I don't know, I'm up for it that's all I can tell you' (P8). }\end{array}$ \\
\hline
\end{tabular}


Table 5 Summary of belief statements and sample quotes from physicians assigned to domains identified as relevant

\begin{tabular}{ll}
\hline Domain & Specific belief \\
\hline $\begin{array}{l}\text { Environmental Context } \\
\text { and Resources }\end{array}$ & $\begin{array}{l}\text { Time is a concern/factor in my } \\
\text { decision to participate. } \\
\text { I would require a research assistant, } \\
\text { another colleague or specialist. }\end{array}$ \\
\end{tabular}

Frequency

(out of 13)

(n (\%))

Sample quote

$13(100)$

$12(92)$

another colleague or specialist.

I would require resources such as information, training, education, learning materials, the protocol and so on.

Funding/cost/remuneration is a factor in my decision to participate.

I would need other tools/support.

7 (54)

9 (69)

8 (62)

$13(100)$

I would consider screening my patients if this trial is available in the next year.

I may not participate in the trial.

$1(8)$

A phase 1 vs phase 2 trial would not affect my motivation to participate in a negative way.

A phase 1 vs phase 2 trial would affect my motivation to participate.

\begin{tabular}{lll} 
Emotion & $\begin{array}{l}\text { Screening would add some level of } \\
\text { stress to my current workload. }\end{array}$ & $13(100)$ \\
\hline $\begin{array}{l}\text { Beliefs about } \\
\text { Consequences }\end{array}$ & This trial could benefit my patients. & $12(92)$
\end{tabular}

There may be no benefit/ disadvantages for my patients.

The trial will be beneficial to me (my career, knowledge, personal achievements/ fulfilment).

This will not benefit me, or there may be disadvantages.

Safety is important.

$8(62)$

I am unsure of the consequences.
'Well if it takes a lot of time, which we don't have a lot of the time that would be a real disincentive to do it' (P1).

'...the \#1 factor driving me to participate is the support I would receive on-site, that would influence me to make the decision in participating. I foresee if we would have supporting staff, for example to take consent, help compile screening questions, to form (an) excel sheet to ensure follow-up/booking and all those little logistics will be taken care of (by) somebody else....' (P4)

'... there would probably have to be a physiotherapist for checking function and an occupational therapist checking the actual outcome measures like speed and dexterity...' (P6)

'Well I guess training on the specific screening tool used. Probably some basic training like research ethics training ...'; 'Education on the actual screening process and the screening tool. And potentially educational information on what the functional assessment measure we're using [is]. And probably just an outline on the actual trial or protocol that's expected in terms of follow-ups, the amount of time, the duration of follow-up, and also the study protocol' (P10).

'It would make my waitlist longer and again, I would not do it if it's not remunerative' (P3). 'We would need the funding to hire staff to do those outcome measures....and then are we allowed to bill [payment system] for this kind of follow up?' (P4).

'... To do this kind of study, you need some facility support. The time and the place that you're doing the screening, that would have to be provided somewhere' (P13). 'Umm I don't think I need to be influenced, but I need to be supported by the hospital...' (P4)

Would you screen your patients as part of a trial of MSCs for clinical stroke if one is available in the next year?) 'If it was shown to be safe, I would help yeah' (P2).

'Yeah. (And why's that?) I have patients interested in it. And I think it's an important question for us in rehabilitation' (P12).

'I just don't see myself engaging in that research' (P13).

'I feel this safety trial is necessary, it is motivating for me' (P4).

'I would still be motivated to do it, but I would just want to make sure that the educational material is reflective of the goal of the trial and that patients understood exactly what they were getting involved in' (P10).

'Yeah I don't think I would be that motivated to do that because l'm in a rural setting and if there are complications or challenges or problems with the injection, I wouldn't be prepared to have to deal with those...' (P3); 'Probably a little less motivated...' (P5).

'Yes. It would add to the workload' (P1). 'Uh, probably, probably not too much, l'd probably be okay, if it was an easy protocol' (P2).

'... Even if this didn't work, at least stroke survivors are aware that we're still always looking out for ways to help them recover, improve their independence. I think that's a very strong, positive message for people. And then if (it's) something that works out, that just becomes part of usual care down the line...' (P3).

'I would hope there would be symptom reduction. I think there's probably enough evidence that there's a chance we might [see] symptom reduction and we might see some signs of improvement...' (P9).

'... It may be a bit of a bit challenging for people who want to be really involved but aren't the right person' (P3).

'For the patients, if they start having problems like transmission of infection, or problems with cell-based tumors which are a potential, umm you know if you get infusion reactions - those are all not necessarily good things' (P5). skills, knowledge for the future of stroke care guidelines, promote academic involvement, promote our site to become a center of excellent, promote research activity' (P4).

'... Of course I will be happy to be involved in the writing process and research and be one of the main investigators and hopefully having publications and being involved in the scientific community. That would be my award, basically' (P11).

'And the fact that disadvantages may result in a negative trial. If it's a negative trial the time isn't necessarily well spent' (P9)

'... there are no immediate benefits - no extra pay and no extra time. You have to squeeze extra time from an already full, fully occupied pie' (P4).

What about the most important factor for you agreeing to participate and screen as a whole?) 'Oh uhh probably the safety profile of the stem cells - if I perceive that this is grossly unsafe l'm not likely to screen' (P5).

'So we really have to know if there are going to be unperceived side effects that we're not aware of at this point at this point possible. Will it work or not work, I think it's still an unanswered question' (P10). 
Table 5 Continued

\begin{tabular}{|c|c|c|c|}
\hline Domain & Specific belief & $\begin{array}{l}\text { Frequency } \\
\text { (out of 13) } \\
\text { (n (\%)) }\end{array}$ & Sample quote \\
\hline \multirow[t]{4}{*}{$\begin{array}{l}\text { Beliefs about } \\
\text { Capabilities }\end{array}$} & $\begin{array}{l}\text { I do feel confident in my ability to } \\
\text { screen/refer patients for this trial. }\end{array}$ & $11(85)$ & $\begin{array}{l}\text { 'I've been doing clinical research for a long time so l'm pretty confident I can do it' (P5). } \\
\text { 'As confident as the tool that you pick for me. If it has inter-rater reliability, then quite } \\
\text { confident' (P6). }\end{array}$ \\
\hline & $\begin{array}{l}\text { I do feel confident in my ability } \\
\text { to perform functional outcome } \\
\text { measures. }\end{array}$ & $7(54)$ & $\begin{array}{l}\text { 'I am very comfortable; I know all the scales... if it's early stage I would say yes' (P4). } \\
\text { 'Certainly, I feel comfortable doing functional outcome measures. (AC: So you do?) Sure' } \\
\text { (P8). }\end{array}$ \\
\hline & $\begin{array}{l}\text { Stress/workload may affect my ability } \\
\text { to participate in the trial. }\end{array}$ & $3(23)$ & $\begin{array}{l}\text { (If it were to add stress to your current work load, how do you think that might influence } \\
\text { your decision to screen for it? Would it make you more reluctant to do it?) 'Yeah. If I looked } \\
\text { at something and was like 'Oh gosh, there's no way that I can fit that in', it certainly would, } \\
\text { yeah' (P8). }\end{array}$ \\
\hline & $\begin{array}{l}\text { Stress/workload would not affect my } \\
\text { ability to participate in the trial. }\end{array}$ & $4(31)$ & $\begin{array}{l}\text { 'I wouldn't just ignore the protocol and be like 'ah sorry I just don't have time to do that } \\
\text { today" (P2). } \\
\text { 'Happy to do it if it doesn't really interfere with what I'm doing now. If it's nothing exceptional } \\
\text { and I can just fit people as a part of my usual day-to-day scheduling then I don't see it as a } \\
\text { problem...' (P3). }\end{array}$ \\
\hline
\end{tabular}

Goals I have other priorities than $10(77)$
participating in this trial.

'So it's not the bottom of the heap it's just if someone gets sick or if you're not sure if they're reluctant, if they don't want to be screened, then obviously I wouldn't try to convince them. I do think it's important so I would not rank it right at the bottom' (P2).

'Well there are definitely going to be times when other things are more priorities for the patients. In the clinic, you might have other things that you're doing so obviously if you get through your clinic, I don't know how often that would happen. But if I was given the criteria and I saw a patient who was appropriate, I think that would be okay. In a busy clinic, that might be a challenge sometimes' (P12)

Screening would be a top priority. $\quad 1$ (8) 'For patients that meet inclusion and exclusion criteria, I can't see that there would be a lot else that would be a higher priority' (P9).

\begin{tabular}{|c|c|c|c|}
\hline \multirow[t]{2}{*}{ Behavioural Regulation } & $\begin{array}{l}\text { I would use a reminder/ a reminder } \\
\text { would be helpful. }\end{array}$ & $9(69)$ & $\begin{array}{l}\text { '...a reminder around my clinic or having an email sent to me from the research coordinator, } \\
\text { or if they were [to] come right to my clinic and say 'Do you have any participants for the study } \\
\text { today?" (P8). } \\
\text { 'Again, if there's something, like a cue on the patients' chart...' (P13). }\end{array}$ \\
\hline & $\begin{array}{l}\text { I would be able to manage my time } \\
\text { and plan ahead. }\end{array}$ & $7(54)$ & $\begin{array}{l}\text { 'Of course we always try to balance the clinical with the research, so we don't want } 50 \\
\text { studies that we're supposed to be screening for and all that' (P2). } \\
\text { 'Oh, I would just have to have a schedule' (P7). }\end{array}$ \\
\hline Optimism & $\begin{array}{l}\text { I would expect/hope for more good } \\
\text { things than bad things. }\end{array}$ & $9(69)$ & $\begin{array}{l}\text { 'I believe a lot of good things should come from that. For example, maximized patients' } \\
\text { recovery and neuroplasticity, implement treatment at (a) very early stage besides } \\
\text { thrombectomy, enhances patient recoveries, I really believe that' (P4). }\end{array}$ \\
\hline
\end{tabular}

$\begin{array}{lll}\text { Knowledge } & \begin{array}{l}\text { I am aware/ have some knowledge of } \\ \text { what 'MSCs' or 'stem cells' are. }\end{array} & 12(92) \\ & \begin{array}{l}\text { I have limited knowledge of 'MSCs'. } \\ \text { I would require more information. }\end{array} & 7(8) \\ & 7(54) \\ \begin{array}{lll}\text { Social/Professional } \\ \text { Role and Identity }\end{array} & \begin{array}{l}\text { Certain aspects of screening could } \\ \text { be a part of my professional role. }\end{array} & 10(77)\end{array}$

(P4)

'In general, I am aware that they are potentially a therapeutic treatment...' (P10).

'I don't know anything about it' (P7).

(54) 'It would really come down to having more information about the treatment, what the plan was, who else is involved, what the risks and benefits were...' (P8).

'I would say potentially it could be, depending what it would entail, the timing. Sort of what the procedure would be, who's involved, I can see it potentially being something that could be able to do here because l've been involved in clinical studies in the past' (P8)

It is my role to refer patients.

'... I do see part of my role as (patients) come through clinics or my colleague's clinics, I would point them to a research coordinator to get them to consent to the study. I'm more like air traffic control (laughs). Of course I cannot consent them because l'm an investigator, but if I wasn't an investigator in the trial the(n) I certainly could... but directing them to the right person for (the) informed consent procedure...' (P5).

Involvement in the trial would align with my role as a clinician/researcher at an academic institution

'I think that part of my role is looking for treatment options...' (P10). 'Yep. Well I'm also a clinician scientist. So it's part of my job, for sure' (P12).

It is not my role to screen patients because of a conflict of interest.

It is not my role to perform functional outcome tests as part of a follow-up appointment.

Social Influences
$\begin{aligned} & \text { The opinions of colleagues and } \\ & \text { other physicians/ researchers could } \\ & \text { have an impact on my decision to } \\ & \text { participate. }\end{aligned}$
$\begin{aligned} & \text { The people running the trial will } \\ & \text { have an impact on my decision to } \\ & \text { participate. }\end{aligned}$
(8) I don't think I would be doing that, if it's someone else's study I would probably ask them
to do it. Depends on what it was, but you know if I'm not involved in the study then I would to do it. Depends on what it was, but you know if I'm not involved in the
suspect that the researcher should be doing that kind of stuff' (P2)

8 (62) 'Well if we're recruiting here then it would be nurse manager, the unit manager, inpatient/ outpatient manager, anyone else it would impact I would imagine' (P2).

'Well, I would probably be interested to know if physiatrists that are doing stroke across Canada, how any of them are interested...' (P3).

'I think the patient's care provider could be useful...' (P13).

'The most important factor would be whoever's running the trial' (P9).

Continued 
Table 5 Continued

\begin{tabular}{|c|c|c|c|}
\hline Domain & Specific belief & $\begin{array}{l}\text { Frequency } \\
\text { (out of 13) } \\
\text { (n (\%)) }\end{array}$ & Sample quote \\
\hline \multirow[t]{2}{*}{$\begin{array}{l}\text { Memory, Attention and } \\
\text { Decision Processes }\end{array}$} & $\begin{array}{l}\text { I may forget about screening for this } \\
\text { trial. }\end{array}$ & $6(46)$ & $\begin{array}{l}\text { Do you think it is likely that you might sometimes forget to screen for this trial? } \\
\text { 'It might happen, yeah' (P12); 'That's a very common phenomenon' (P9). }\end{array}$ \\
\hline & $\begin{array}{l}\text { I do not think it's likely that I will } \\
\text { forget to screen. }\end{array}$ & $5(38)$ & $\begin{array}{l}\text { 'No, that's not me. For any trial either I am PI or co-PI and if I commit to this task then I } \\
\text { remember' (P4). } \\
\text { 'I don't think so. It certainly hasn't been an issue in the past. But sometimes you do have a } \\
\text { busy clinic and you get through and you're 'oh I should ask them about this study'. Usually it } \\
\text { hasn't been an issue in the past, I don't think it's very likely' (P8). }\end{array}$ \\
\hline \multirow[t]{2}{*}{ Skills } & $\begin{array}{l}\text { I have performed functional outcome } \\
\text { tests in the past. }\end{array}$ & $6(46)$ & $\begin{array}{l}\text { Have you ever performed functional outcome tests? (eg, National Institutes of Health Stroke } \\
\text { Scale/Score (NIHSS), modified Rankin Scale (mRS), Barthel Index (BI), Activities of Daily } \\
\text { Living (ADL)) 'Yes' (P7). }\end{array}$ \\
\hline & $\begin{array}{l}\text { I have not performed stroke } \\
\text { functional outcome tests in the past. }\end{array}$ & $3(23)$ & Have you ever performed any functional outcome tests? 'No' (P2). \\
\hline
\end{tabular}

MSCs, mesenchymal stem cells.

a safety trial, although some physicians expressed that they would be less motivated. Physicians who suggested their motivation would be decreased also noted, however, that they understood these types of trials need to be completed.

\section{Physician key theme 3: involvement aligns with professional role} but resources are needed

Although most physicians agreed that being involved in a cell therapy trial could be a part of their professional role, a few also expressed concern that screening their own patients may result in bias or patients feeling pressured to participate. Many potential barriers to physicians' involvement in the trial were identified. All physicians stated that they would require additional time and resources to participate. Every physician suggested that screening would add to their workload and associated stress levels, though to varying degrees. Most of the physicians suggested that additional staff to screen and help coordinate ongoing care would ameliorate these stresses and concerns. Other additional resources were also frequently mentioned including background material, information to relay to patients, education and training, and costs to cover such training.

Physician key theme 4: colleagues and researchers may influence physicians' participation (social influences)

Most physicians expressed that the opinions of colleagues, other physicians and researchers would impact their decision to participate. A small proportion also noted that those running the trial would influence their decision to participate; in particular, trusting the principal investigator was important.

\section{DISCUSSION}

The findings from this study point to several key considerations that will influence the development of a feasible clinical trial protocol. Our study is novel in that it assessed these views in a comprehensive manner prior to initiating a resource-intensive cell therapy trial. This is in contrast to a previous retrospective narrative that detailed encountered barriers to cell therapy trials for stroke. ${ }^{11} \mathrm{We}$ detail key findings and potential implications for future clinical trials.

There has been little work assessing potential barriers and enablers to both patient participation and physician involvement in early phase clinical trials. This is an important knowledge gap as considerations to take part in such trials may differ substantially from those to take part in a later phase trial where safety is better established and trial outcomes focus on measuring benefits. Encouragingly, both patients and physicians showed interest in an MSC therapy trial for chronic stroke. This is an important finding as previous studies have found that investigators may overestimate enthusiasm for experimental trials. ${ }^{245}$ Within the domain of chronic stroke therapy, however, we found a clear appetite for studies evaluating stem cell therapy.

Safety of the therapy was an important issue to both patients and physicians. Our finding is consistent with two previous systematic reviews ${ }^{9} 10$ that identified concern of the uncertainty surrounding trials as a commonly cited barrier to patient participation. These reviews also identified physicians' 'concern for patients ${ }^{9}$ or 'gate keeping on behalf of the patients' ${ }^{10}$ as potential barriers. When considering future clinical trials of MSC therapy, physicians may benefit from receiving clear information on the safety of MSCs (eg, systematic review) ${ }^{26}$ This may help to increase physician comfort and confidence. Patients may similarly benefit from further information on the safety of MSCs; however, further work is required to determine how best to convey this information to patients.

Perhaps surprisingly, almost all patients expressed that inclusion of a placebo group would not impact their decision to participate. This is contrary to previous literature that has reported randomisation as a potential barrier to patient recruitment. ${ }^{9} 102728$ Our finding may reflect the fact that chronic stroke is an under-researched area $^{1}$ and, as a result, there is a strong appetite among patients to participate in evaluations of promising new therapies. This finding underscores the importance of conducting trial specific assessments and not assuming patient 
barriers. Based on our findings, randomised controlled trials or cross-over cell therapy trials may be attractive study designs for some chronic stroke patients.

Our interviews with patients also allowed us to identify important patient considerations and preferences. A recent review on the use of cell therapy for treatment of stroke highlighted that patients sometimes have ethical concerns with 'stem cells'. ${ }^{11}$ Patients may mistakenly believe that stem cells can only be procured from embryos, ${ }^{11}$ while in reality they can be collected from other sources (eg, bone marrow). Counter to this, our interview study found that only one patient voiced ethical concerns over the use of stem cell therapy.

All interviewed patients identified that health benefits and/or functional improvement would be an important goal for the trial. This finding may help guide selection of outcomes in clinical trials to help ensure the data collected is of interest to patients. Many patients also voiced that the method of MSC administration would affect their decision to participate. Thus, offering the preferred route of administration in a clinical trial may attract more patients to enrol. Furthermore, similar to previous reviews, ${ }^{9} 10$ providing support to address logistical issues, such as transportation, was identified as a potential enabler. Allocating funds to ensure patients have appropriate transportation and additional living costs may be an important consideration for future trials.

Despite physicians' interest in an MSC trial, many potential barriers to their involvement were identified. Some of these barriers have been identified in previous publications. For instance, concerns regarding time and recruitment's effects on relationships with patients have been identified as physician barriers, ${ }^{910}$ as well as insufficient training and limited availability of staff. ${ }^{9}$

Our study provides an overview of factors that may influence participation in a planned early phase clinical trial of MSC therapy for stroke. These findings address an important gap in the literature, as previous reviews have focused on barriers and enablers of late phase trials. ${ }^{9} 10$ Another strength is that our interview guide was developed from the TDF, which encompasses a broad range of theoretical perspectives. ${ }^{12} 16$

Our study has limitations that should be considered. Those who participated may be generally more open to research and may hold different views compared with those who declined to participate. Furthermore, patient participants may have been more likely to be from a higher socioeconomic position (SEP) ${ }^{29-32}$; their barriers may differ from those of a sample with lower SEP. Patients within our sample also tended to be of older age and male. However, we anticipated that most patients would be of older age, as age is a risk factor for stroke. ${ }^{33}$ Future studies should aim to recruit a balanced sample of both males and females, as well as measure SEP and educational level to better describe the study population. Another limitation of our study is that only English-speaking participants were included. Future studies investigating perspectives in other languages will be valuable and important for trial recruitment from an equity of access perspective. An alternative study design (such as a survey) may be needed to confirm our results in a broader sample ${ }^{13}$; however, because this was a relatively novel topic, we conducted a comprehensive interview study to elicit discussion and understanding.

\section{Summary}

Application of the TDF was valuable in identifying potential barriers and enablers to trial participation from the perspective of two key stakeholders: patients and clinicians. By engaging directly with patients, we were able to identify their preferences in terms of the method of administration, support, and trial outcomes. Interviews with physicians also yielded important information on their training and resource needs. Findings of this study will help refine the design and conduct of our planned MSC therapy trial.

Our approach also helps to build on existing literature of perceived barriers and enablers to early phase clinical trials; some of these findings may be transferrable to other trials. Investigators conducting future early phase cell therapy trials should consider the importance of developing clear information on the safety of the therapy for both physicians and patients; moreover, codevelopment of these educational materials may ensure that particular concerns are addressed in a comprehensive and understandable manner. Additionally, as both physicians and family members were found to be important social influences in a patient's decision to participate, this should be considered when designing the recruitment approach. Our findings suggest that arranging for physicians to be available to discuss the trial with patients and their caregivers would be helpful. More generally, the methodological approach taken, which draws on a comprehensive framework of factors that may influence decisions, motivation and ultimately action (in this case, participating in and conducting a cell therapy trial), may itself be a valuable approach to inform and optimise other future similar trials.

We found this qualitative approach valuable in confirming interest for the trial. Study findings also showed us that participant barriers should not be assumed and that rather patients should be asked and involved. Despite researchers suggesting potential concerns, ${ }^{11}$ we found that patients did not have ethical concerns surrounding the use of stem cells, nor would a placebo necessarily deter them from participating. We encourage other investigators to take this approach when developing future trials to identify barriers and enablers a priori, as this will help to improve the design of the trial to better meet the needs of both patients and physicians.

\section{Author affiliations}

${ }^{1}$ Department of Anesthesiology and Pain Medicine, The Ottawa Hospital, Ottawa, Ontario, Canada

${ }^{2}$ Clinical Epidemiology Program, Blueprint Translational Research Group, Ottawa Hospital Research Institute, Ottawa, Ontario, Canada 
${ }^{3}$ School of Epidemiology and Public Health, University of Ottawa, Ottawa, Ontario, Canada

${ }^{4}$ Department of Medicine, University of Ottawa, Ottawa, Ontario, Canada

${ }^{5}$ Ottawa Hospital Research Institute, Ottawa, Ontario, Canada

${ }^{6}$ Faculty of Medicine, University of Ottawa, Ottawa, Ontario, Canada

${ }^{7}$ Department of Rehabilitation, Pembroke Regional Hospital, Pembroke, Ontario, Canada

\section{Twitter Manoj M Lalu @manojlalu}

Acknowledgements The authors would like to thank the patients and physicians for volunteering their time to participate in this study.

Contributors MML and DAF: conception and design, methodology, provision of study material, manuscript writing and supervision. MF: data analysis and interpretation and manuscript writing. JP and DD: conception and design, methodology, provision of study material and manuscript writing. GC: manuscript writing. AC, JZ and YYD: collection and assembly of data, data analysis and interpretation and manuscript writing. WT: collection and assembly of data, data analysis and interpretation. DT: provision of study patients and manuscript writing. PJ: collection and assembly of data and final approval of manuscript.

Funding The authors have not declared a specific grant for this research from any funding agency in the public, commercial or not-for-profit sectors.

Competing interests None declared.

Patient consent for publication Not required.

Ethics approval Ethics approval was obtained from the Ottawa Health Science Network Research Ethics Board (20160708-01H) and the Pembroke Regional Hospital.

Provenance and peer review Not commissioned; externally peer reviewed.

Data availability statement Data are available on reasonable request. The data that support the findings of this study are available from the corresponding author on reasonable request.

Open access This is an open access article distributed in accordance with the Creative Commons Attribution Non Commercial (CC BY-NC 4.0) license, which permits others to distribute, remix, adapt, build upon this work non-commercially, and license their derivative works on different terms, provided the original work is properly cited, appropriate credit is given, any changes made indicated, and the use is non-commercial. See: http://creativecommons.org/licenses/by-nc/4.0/.

ORCID iD

Manoj M Lalu http://orcid.org/0000-0002-0322-382X

\section{REFERENCES}

1 Briggs R, O'Neill D. Chronic stroke disease. Br J Hosp Med 2016;77:C66-9.

2 Chopp M, Li Y. Treatment of neural injury with marrow stromal cells. Lancet Neurol 2002;1:92-100.

3 Lee S-T, Chu K, Jung K-H, et al. Anti-Inflammatory mechanism of intravascular neural stem cell transplantation in haemorrhagic stroke. Brain 2008;131:616-29.

4 Kim Y-J, Park H-J, Lee G, et al. Neuroprotective effects of human mesenchymal stem cells on dopaminergic neurons through antiinflammatory action. Glia 2009;57:13-23.

5 Tohill M, Mantovani C, Wiberg M, et al. Rat bone marrow mesenchymal stem cells express glial markers and stimulate nerve regeneration. Neurosci Lett 2004;362:200-3.

6 Lalu MM, Montroy J, Dowlatshahi D, et al. From the lab to patients: a systematic review and meta-analysis of mesenchymal stem cell therapy for stroke. Trans/ Stroke Res 2019. doi:10.1007/s12975-01900736-5. [Epub ahead of print: 25 Oct 2019].

7 Huang GD, Bull J, Johnston McKee K, et al. Clinical trials recruitment planning: a proposed framework from the clinical trials transformation initiative. Contemp Clin Trials 2018;66:74-9.

8 Treweek S, Lockhart P, Pitkethly M, et al. Methods to improve recruitment to randomised controlled trials: cochrane systematic review and meta-analysis. BMJ Open 2013;3:e002360.
9 Ross S, Grant A, Counsell C, et al. Barriers to participation in randomised controlled trials: a systematic review. J Clin Epidemiol 1999;52:1143-56.

10 Fayter D, McDaid C, Eastwood A. A systematic review highlights threats to validity in studies of barriers to cancer trial participation. $J$ Clin Epidemiol 2007;60:990.e1-990.e33.

11 Misra V, Hicks WJ, Vahidy F, et al. Recruiting patients with stroke into cell therapy trials: a review. JAMA Neurol 2016;73:1141-4.

12 Michie S, Johnston M, Abraham C, et al. Making psychological theory useful for implementing evidence based practice: a consensus approach. Qual Saf Health Care 2005;14:26-33.

13 Atkins L, Francis J, Islam R, et al. A guide to using the theoretical domains framework of behaviour change to investigate implementation problems. Implement Sci 2017;12:77.

14 Guillot M, Asad S, Lalu MM, et al. So you want to give stem cells to babies? neonatologists and parents' views to optimize clinical trials. $J$ Pediatr 2019;210:e41:41-7.

15 Presseau J, Mutsaers B, Al-Jaishi AA, et al. Barriers and facilitators to healthcare professional behaviour change in clinical trials using the theoretical domains framework: a case study of a trial of individualized temperature-reduced haemodialysis. Trials 2017;18:227.

16 Cane J, O'Connor D, Michie S. Validation of the theoretical domains framework for use in behaviour change and implementation research. Implement Sci 2012;7:37.

17 Foy R, Francis JJ, Johnston M, et al. The development of a theorybased intervention to promote appropriate disclosure of a diagnosis of dementia. BMC Health Serv Res 2007;7:207.

18 Francis JJ, Presseau J. Healthcare practitioner behaviour. In: Llewellyn C, Ayers S, McManus C, eds. Cambridge Handbook of psychology, health and medicine. 3rd ed. Cambridge: Cambridge University Press, 2019.

19 Presseau J, McCleary N, Lorencatto F, et al. Action, actor, context, target, time (AACTT): a framework for specifying behaviour. Implement Sci 2019;14:102.

20 Francis JJ, Johnston M, Robertson C, et al. What is an adequate sample size? Operationalising data saturation for theory-based interview studies. Psychol Health 2010;25:1229-45.

21 Hsieh H-F, Shannon SE. Three approaches to qualitative content analysis. Qual Health Res 2005;15:1277-88.

22 Islam R, Tinmouth AT, Francis JJ, et al. A cross-country comparison of intensive care physicians' beliefs about their transfusion behaviour: A qualitative study using the theoretical domains framework. Implementation Sci 2012;7:93.

23 Patey AM, Islam R, Francis JJ, et al. Anesthesiologists' and surgeons' perceptions about routine pre-operative testing in low-risk patients: application of the Theoretical Domains Framework (TDF) to identify factors that influence physicians' decisions to order preoperative tests. Implementation Sci 2012;7:52.

24 Tognoni G, Alli C, Avanzini F, et al. Randomised clinical trials in general practice: lessons from a failure. BMJ 1991;303:969-71.

25 Foley JF, Moertel CG. Improving accrual into cancer clinical trials. J Cancer Educ 1991;6:165-73.

26 Zheng $\mathrm{H}$, Zhang B, Chhatbar PY, et al. Mesenchymal stem cell therapy in stroke: a systematic review of literature in pre-clinical and clinical research. Cell Transplant 2018;27:1723-30.

27 Jack WJ, Chetty U, Rodger A. Recruitment to a prospective breast conservation trial: why are so few patients randomised? BMJ 1990;301:83-5.

28 Llewellyn-Thomas HA, McGreal MJ, Thiel EC, et al. Patients' willingness to enter clinical trials: measuring the association with perceived benefit and preference for decision participation. Soc Sci Med 1991;32:35-42.

29 Goyder J, Warriner K, Miller S. Evaluating socio-economic status (Ses) bias in survey nonresponse. J Off Stat 2002;18:1-11.

30 Niebuur J, van Lente L, Liefbroer AC, et al. Determinants of participation in voluntary work: a systematic review and metaanalysis of longitudinal cohort studies. BMC Public Health 2018;18:1213.

31 Jang $M$, Vorderstrasse A. Socioeconomic status and racial or ethnic differences in participation: web-based survey. JMIR Res Protoc 2019;8:e11865.

32 Langhammer A, Krokstad S, Romundstad P, et al. The HUNT study: participation is associated with survival and depends on socioeconomic status, diseases and symptoms. BMC Med Res Methodol 2012;12:143.

33 Boehme AK, Esenwa C, Elkind MSV, et al. Stroke risk factors, genetics, and prevention. Circ Res 2017;120:472-95. 